\title{
Loess in Europe
}

\author{
Guest Editorial
}

\author{
Manfred Frechen
}

Address of author: M. Frechen, Leibniz Institute for Applied Geophysics (LIAG), Geochronology \& Isotope Hydrology, Stilleweg 2, 30655 Hannover, Germany. E-Mail: Manfred.Frechen@liag-hannover.de

The papers of this Special Issue give remarkable new results and conclusions on loess from Europe underlining the excellence of loess archives for past climate and environment reconstructions from a local and regional perspective and their relationship to a more global interpretation (FRECHEN 2011 a, b). Loess is a clastic predominantly silt-sized sediment, which is formed by the accumulation of wind-blown dust. According to PyE (1995) four fundamental requirements are necessary for it formation: a dust source, adequate wind energy to transport the dust, a suitable accumulation area, and a sufficient amount of time. During the Quaternary, loess and loess-like sediments were formed in periglacial environments on mid-continental shield areas in Europe and Siberia, on the margins of high mountain ranges like in Tajikistan and on semi-arid margins of some lowland deserts like in China.

The term "Löß" was first described in Central Europe by KARL CÄSAR VON LEONHARD (1823/24) who reported yellowish brown, silty deposits along the Rhine valley near Heidelberg. Charles Lyell (1834) brought this term into widespread usage by observing similarities between loess and loess derivatives along the loess bluffs in the Rhine and Mississippi. At that time it was thought that the yellowish brown silt-rich sediment was of fluvial origin being deposited by the large rivers. It took until the end of the $19^{\text {th }}$ century until the aeolian origin of loess was recognized (VIRLET D'Aoust 1857), especially the convincing observations of loess in China by FERDINAND von Richthofen's (1878). A tremendous number of papers have been published since then, focusing on the formation of loess and on loess/palaeosol sequences as archives of climate and environment change (e.g. PYe 1995; SMALley 1995; PÉCSI \& RICHTER 1996).

Much effort was put into the setting up of regional and local loess stratigraphies and their correlation (KuKLA 1970, 1975, 1977). But even the chronostratigraphical position of the last interglacial soil correlating to marine isotope substage 5e has been a matter of debate, owing to the lack of robust and reliable numerical dating, as summarized for example in Zöller et al. (1994) and Frechen, HorvÁth \& GÁBRIs (1997) for the Austrian and Hungarian loess stratigraphy, respectively.

Since the 1980s, thermoluminescence (TL), optically stimulated luminescence (OSL) and infrared stimulated lumines- cence (IRSL) dating are available providing the possibility for dating the time of loess (dust) deposition, i.e. the time elapsed since the last exposure of the mineral grains to daylight. During the past decade luminescence dating has significantly improved by new methodological improvements, especially the development of single aliquot regenerative (SAR) protocols (MURRAY \& WINTLE 2000) resulting in reliable ages (or age estimates) with an accuracy of up to 5 and $10 \%$ for the last glacial record. More recently luminescence dating has also become a robust dating technique for penultimate and antepenultimate glacial loess (e.g. THIEL et al. this issue; SchmidT et al. this issue) allowing for a reliable correlation of loess/palaeosol sequences for at least the last two interglacial/glacial cycles throughout Europe and the Northern Hemisphere (FRECHEN 2011a). Furthermore, the numerical dating provides the basis for quantitative loess research applying more sophisticated methods to determine and understand high-resolution proxy data, such as the palaeodust content of the atmosphere, variations of the atmospheric circulation patterns and wind systems, palaeoprecipitation and palaeotemperature.

The papers of this Special Issue on Loess in Europe give the basis for substantial further challenging developments in loess research and are summarised geographically from north to south.

Little is known about the timing of loess accumulation and soil formation as well as the settlement history in the "Altmoränengebiet" in northern Germany. URBAN, Kunz \& GeHRT (this issue) provide some evidence for the human impact on soil development since the late Neolithic by means of sedimentology, pedology and palynology as well as OSL and radiocarbon dating.

WAGNER (this issue) carried out a spatial compilation and visualisation of loess parameters for loess and loess-like sediments in the Weser-Aller catchment, including parts of southern Lower Saxony and northern Hesse in Northwest Germany. In this study, very detailed maps of loess property patterns including loess thickness, granulometry and stratigraphy were collected from publications and historically maps published between 1876 and 2007 resulting in more than 600 loess locations providing the base information for the area under study.

The loess/palaeosol sequences from Saxony were re-investigated by MEszner, Fuchs \& FAust (this issue), who 
present a new composite profile including new stratigraphic marker horizons and palaeosols. They identified three palaeosols for the so far poorly differentiated Weichselian Pleniglacial record in Saxony.

In the Lower Rhine Embayment, detailed loess/palaleosol sequences have been described from the km-wide exposures of the brown coal open-cast mines and from many brickyards, e.g. Grafenberg, Rheindahlen and Erkelenz. Most of the studied sections give evidence for rich Palaeolithic (and younger periods) artefacts and settlement structures. PAwlik \& Thissen (this issue) present results from a Middle Palaeolithic archaeological layer in the open cast brown coal mine Inden, which they correlate to the Eemian interglacial. The studied artefacts give evidence for birch pitch fixed tools, either as hafted impliments fixed with birch pitch onto shafts or being used for successive hafting-and-retroling activities. PAWLIK $\approx$ ThIssen (this issue) point out that birch pitch residues evidence human use of adhesive and multicomponent tool making already in the Middle Palaeolithic.

At the Schwalbenberg section, a very detailed Weichselian Middle Pleniglacial loess record is exposed (Frechen \& SchIRmer this issue). Eight weak interstadial palaeosols including Ah and Bcv (calcic cambisol) horizons are intercalated in loess and reworked loess. The chronostratigraphical units show little or no age increase with depth indicating fast accumulation of sediment and fast formation of the soils; similar observations were made for the Early Weichselian record at the Tönchesberg section (BOENIGK \& FrECHEN 2001).

Maar lakes and dry maars of the West Eifel Volcanic Field are excellent sediment traps and provide sediment records with the possibility to archive event-laminated sediments. Dietrich $\&$ Sirocko (this issue) describe the potential of micro X-ray fluorescence ( $\mu \mathrm{XRF}$ ) scanning to study bulk sediment chemical data for major and trace elements in maar lake sediments to determine the elemental stratification within sediment cores. The cores under study from the Dehner dry maar and the Schalkenmehren maar show both fully glacial as well as warm and wet climate conditions and give evidence for the major dust deposition events. DiETRICH $\mho$ SIRocko (this issue) show evidence that a combination of the Ca content and the grayscale values correlates best with the signal of aeolian sediment input.

Reliable dating of maar sediments is a real challenge. ScHmidT et al. (this issue) studied sediments from the Jungfernweiher located in the West Eifel Volcanic Field using luminescence dating. The IRSL dating study indicates that the sediments from $16 \mathrm{~m}$ below surface have luminescence age of $250 \mathrm{ka}$ and increase up to $400 \mathrm{ka}$ for the oldest sampled sediments about $94 \mathrm{~m}$ below modern surface. However, one of the co-authors (F. Sirocko, see appendix of SchmidT et al. this issue a) has a different interpretation based on radiocarbon dating and further relative dating methods, such as sediment magnetisation, tuning of greyscale variations with Greenland ice core and intercalated tephra horizons indicating a last glacial record. The different opinions show that chronological approaches are very challenging.

At the gravel quarry Gaul located near Weilbach in the southern foreland of the Taunus Mountains, a Middle to Upper Pleistocene loess/palaleosol sequence is exposed correlating with the last three glacial cycles. The oldest loess gave post-IR IRSL at $225^{\circ} \mathrm{C}$ age estimates of at least $350 \mathrm{ka}$ (MIS 10) ago (Schmidt, Semmel \& Frechen this issue). A humicrich horizon ("Weilbacher Humuszone") correlates to the late phase of the penultimate interglacial (MIS 7). The uppermost loess correlates to the Upper Würmian.

THIEL et al. (this issue) investigated three important Pleistocene key loess sections in Lower Austria, these are Joching, Paudorf and Göttweig. The post-IR IRSL age estimates allow for a correlation of the pedocomplex "Paudorfer Bodenbildung" with the last interglacial (MIS 5), which is in agreement with previous TL age estimates of ZöLLER et al. (1994). However, the pedocomplex "Göttweiger Verlehmungszone" is signifiacantly older $(\geq 350 \mathrm{ka})$ than the last interglacial soil. ThiEL et al. (this issue) found out that discontinuities in loess/palaeosol records observed in Lower Austria are significant making a simple counting from the top approach unreliable. Thus, the Lower Austrian loess stratigraphy including the timing of the intercalated palaeosols remains under discussion and requires further luminescence based age determination.

Loess deposits from the Hagenbach Klamm located in the northern Vienna Forest were dated using luminescence dating by FrANK et al. (this issue). The mollusc assemblages indicate very humid and cool climatic conditions for the Upper Pleniglacial (Upper Würmian). FrANk et al. (this issue) observed good agreement between malcalogical results and those of numerical dating including ${ }^{14} \mathrm{C}$ and IRSL ages. The dating results make a loess accumulation prior to the Last Glacial Maximum most likely.

ZECH et al. (this issue) give an overview on the most recent proxy developments concerning biomarkers and compound-specific stable isotopes. The aim of these novel methodological approaches is to determine more quantitative palaeoclimate proxies for reconstruction of vegetation history, palaeotemperature and palaeoclimate/aridity.

WACHA et al. (this issue) investigated a very detailed loess/palaeosol sequence on Susak. Radiocarbon ages and luminescence age estimates indicate an Upper Pleistocene record including a very detailed and thick Middle Pleniglacial record (MIS 3) including numerous intercalated palaleosols and at least three tephra layers, most likely from the Italian Volcanic provinces. The island of Susak is unique in the North Adriatic Sea because the geomorphology of the island has all characteristics of a loess plateau dissected by numerous gorges, steep bluffs and gullies (WACHA et al. this issue).

The Late Pleistocene/Holocene morphological and geological history of the Paraguayan Chaco and the Argentine Pampa Plain (Chaco-Pampa Plain) was studied by Kruck et al. (this issue). Satellite images were used to synthesise previous and new multidisciplinary results of this vast-extended area. KRUCK et al. (this issue) localised source regions of loess, loess-like sediments and sandy deposits in the southwestern Pampa and the neighbouring Andean slopes and the Altiplano, thus indicating a sediment transport towards east and later northeast. 


\section{References}

Boenigk, W. $\&$ Frechen, M. (2001): The loess record in sections at KoblenzMetternich and Tönchesberg in the Middle Rhine Area. - Quaternary International, 76/77: 201-209.

Dietrich, S. \& Sirocko, F. (this issue): The potential of dust detection by means of !XRF scanning in Eifel maar lake sediments. - Quaternary Science Journal (EuG), 60 (1).

Frank, C., Terhorst, B., Damm, B., Thiel, C., Frechen, M. \& Peticzka, R (this issue): Pleistocene loess deposits and mollusc assemblages in the Eastern Pre-Alps. - Quaternary Science Journal (EuG), 60 (1).

Frechen, M. (2011a): Loess in Eurasia. - Quaternary International, xyxy, $1-3$.

Frechen, M. (2011b): Timing and Vegetation History of Interglacials in northern Eurasia. - Quaternary International, 141: 1-2.

Frechen, M., Horváth, E. \& GÁBrIs, G. (1997): Geochronology of Middle and Upper Pleistocene loess sections in Hungary. - Quaternary Research, 48: 291-312.

Frechen, M. \& SCHIRMER, W. (this issue): Luminescence Chronology of the Schwalbenberg II Loess in the Middle Rhine Valley. - Quaternary Science Journal (EuG), 60 (1).

Kruck, W., Helms, F., Geyh, M.A., Suriano, J.M., Marengo, H.G. d Pereyra, F. (this issue): Late Pleistocene-Holocene History of ChacoPampa Sediments in Argentina and Paraguay. - Quaternary Science Journal (EuG), 60 (1).

KuKLA, G. (1970): Correlation between loesses and deep-sea sediments. Geologiske Foreningen Foerhandlingar, 92: 148-180; Stockholm.

KukLA, G.J. (1975): Loess stratigraphy of Central Europe. - In K.W. Butzer and G.L. Isaac, Eds., After the Australopithecus, pp. 99-188; Mouton, The Hague.

KukLA, G.J. (1977): Pleistocene Land-Sea Correlations I. Europe. Earth Science Reviews, 13: 307-374.

LEONHARD, K.C. von (1823/24): Charakteristik der Felsarten. - 3 Vols., J. Engelmann Verlag Heidelberg, pp. 772.

LyeLL, C. (1834): Observations on the loamy deposits called"loess" of the basin of the Rhine. - Edinburgh New Philosophical Journal, 17: 110-113, $118-120$.

Meszner, S., Fuchs, M. \& Faust, D. (this issue): Loess-Palaeosol-Sequences from the loess area of Saxony (Germany). - Quaternary Science Journal (EuG), 60 (1).

Murray, A. S. ¿ Wintle, A. G. (2000): Luminescence dating of quartz using an improved single aliquot regenerative-dose protocol. Radiation Measurements 32: 57-73

Novothny, A., Horvath, E. \& Frechen, M. (2002): The loess profile at Albertirsa, Hungary - improvements in loess stratigraphy by luminescence dating. - Quaternary International, 95-96: 155-163.
Pawlik, A.F. \& Thissen, J. (this issue): The 'Palaeolithic Prospection in the Inde Valley' Project. - Quaternary Science Journal (EuG), 60 (1).

PÉcsi, M. (1990): Loess is not just the accumulation of dust. - Quaternary International, 7/8: 1-21.

PÉcsi, M. \& Richter, G. (1996): Löss: Herkunft - Gliederung - Landschaften. - Zeitschrift für Geomorphologie, Neu Folge Supplementband 98, Berlin.

Pye, K. (1995): The nature, origin and accumulation of loess.- Quaternary Science Reviews, 14: 653-667.

Richthofen, F. von (1878): Bemerkungen zur Lößbildung. - Verh Geol Reichsanst, Berlin, pp 1-13.

Schmidt, E.D., Semmel, A. \& Frechen, M. (this issue): Luminescence dating of the loess/palaeosol sequence at the gravel quarry Gaul/Weilbach, Southern Hesse (Germany). - Quaternary Science Journal (EuG), 60 (1).

Schmidt, E.D., Murray, A.S., Sirocko, F., Tsukamoto, S. \& Frechen, M. (this issue): IRSL Signals from Maar Lake Sediments Stimulated at Various Temperatures. - Quaternary Science Journal (EuG), 60 (1).

SMALLEY, I. (1995): Making the material: the formation of silt-sized promary mineral paricles for loess deposits. - Quaternary Science Reviews, 14 645-651.

Thiel, C., Buylaert, J.P., Murray, A.S., Terhorst, B., Tsukamoto, S. Frechen, M. \& Sprafke, T. (this issue): Investigating the chronostratigraphy of prominent palaeosols in Lower Austria using post-IR IRSL dating. - Quaternary Science Journal (EuG), 60 (1).

Urban, B., KunZ, A., Gehrt, E. (this issue): Genesis and dating of Late Pleistocene-Holocene soil sediment sequences from the Lüneburg Heath, Northern Germany. - Quaternary Science Journal (EuG), 60 (1).

VIRLET D'Aoust, P.T. (1857): Observations sur un terrain d'origine météorique ou de transport aerien qui existe au Mexique et sur le phénomène des trombes de poussière auquel il doit principalement son origine. - Geol. Soc. France, Full., 2d, Ser. 2, 129-139.

Wacha, L., Mikulcic Pavlakovic, S., Frechen, M., Crnjakovic, M. (this issue): The Loess Chronology of the Island of Susak, Croatia. - Quaternary Science Journal (EuG), 60 (1).

WAGNER, B. (this issue): Spatial analysis of loess and loess-like sediments in the Weser-Aller catchment (Lower Saxony and Northern Hesse, NW Germany). - Quaternary Science Journal (EuG), 60 (1).

ZeCh, M., ZeCH, R., Buggle, B., ZöLler, L. (this issue): Novel methodological approaches in loess research - interrogating biomarkers and compound-specific stable isotopes. - Quaternary Science Journal (EuG), 60 (1).

ZöLLER, L., Oches, E.A.. \& McCoy, W.D. (1994): Towards a revised chronostratigraphy of loess in Austria with respect to key sections in the Czech Republic and in Hungary. - Quaternary Geochronology (Quaternary Science Reviews), 13: 465-472. 